\title{
Radiobiology of Spinal Cord Re-Irradiation: Effect of Time, Dose and Fractionation
}

\author{
Helena Alves $^{1,2}$ and Isabel Bravo ${ }^{2 *}$ \\ ${ }^{1}$ Department of Physics and Astronomy, Faculty of Science, University of Porto, Portugal \\ ${ }^{2}$ Medical Physics and Radiobiology Group, Portuguese Oncology Institute of Porto (IPO Porto), Portugal \\ *Corresponding author: Isabel Bravo, Medical Physics and Radiobiology Group, IPO Porto, Research Center (CI-IPOP), Portuguese \\ Oncology Institute of Porto (IPO Porto), Porto, Portugal
}

\section{ARTICLE INFO}

Received: 幽 December 11, 2019

Published: 櫘 December 17, 2019

Citation: Helena Alves, Isabel Bravo. Radiobiology of Spinal Cord Re-Irradiation: Effect of Time, Dose and Fractionation. Biomed J Sci \& Tech Res 23(5)-2019. BJSTR. MS.ID.003977.

Keywords: Spinal Cord; Radiobiology; Reirradiation; Tolerance

\section{ABSTRACT}

Advances in biology and physics have allowed increased precision and accuracy in Radiotherapy (RT) in order to maximize tumor damage and to minimize lesions in the dose limiting adjacent normal tissues. The spinal cord is the most critical organ (OAR) at risk. Radiation myelopathy is one of the most devastating complications of clinical radiotherapy resulting in severe and irreversible morbidity. As a result of greater accuracy and effectiveness of cancer treatment, patient survival rates increase, and radiation oncologists are frequently faced with the problem of treatment of local recurrence or second tumors located within or close to previously treated sites. Assessment of the impact of dose and fractionation schemes on tissue tolerance has been a major area of research in radiation oncology. Initial dose influences different time intervals from tissue tolerance to reirradiation as well as conditioning the recovery of radiation damage in the first treatment. A comprehensive search was performed including relevant articles referring to "spinal cord", "reirradiation" and "myelopathy". The Biologically Effective Dose (BED) was calculated and the results are discussed considering radiobiological mechanisms.

Abbreviations: BED: Biologically Effective Dose; RT: Radiotherapy; SSB: SingleStrand Breaks, DSB: Double-Strand Breaks; NHEJ: Non-Homologous End Joining; HR: Homologous Recombination; FSU: Functional Subunits; SRS: Spine Stereotactic Radiosurgery; SBRT: Spine Stereotactic Body Radiation Therapy; RM: Radiation Myelopathy

\section{Introduction}

Advances in biology and physics have allowed increased precision and accuracy in radiotherapy in order to maximize tumor damage and to minimize lesions in the dose limiting adjacent normal tissues. This led to an evolution in the treatment of tumors and consequently patient survival rates have been increasing for a wide variety of malignancies. The dose of radiation that can be delivered for tumor control is limited by late and generally irreversible injury of the surrounding normal tissues and organs at risk (OAR), also known as late effects. As a result of greater effectiveness of cancer treatment, radiation oncologists are frequently faced with the treatment of local recurrence or secondary tumors located within or close to previously treated sites. When assessing tumor reirradiation, it is necessary to consider whether the dose of tolerance of an organ has already been reached in the first course of treatment. Treating an area that had prior radiation is far more complex than the initial Radiotherapy (RT) treatment. The spinal cord is the most critical organ at risk. It is typically located near the vertebral tumor target volume and has been classically described as an organ with a serial functional architecture and as such damage to small volumes within the structure can have a major impact on neurologic function [1].

Spinal cord thus limits the dose to tumors in the head and neck, thoracic and upper abdominal regions as well as in cases of bone metastasis in the spine (this is estimated to occur in about $40 \%$ of cancer patients) [2]. 
Key reirradiation parameters evaluated in the decision process include [3]:

I. Total dose / Dose per fraction

II. Spinal cord volume and region irradiated in the first course of RT

III. Time elapsed since the first treatment.

Radiation myelopathy is one of the most devastating complications of clinical radiotherapy resulting in severe and irreversible morbidity. Assessment of the impact of dose and fractionation schemes on tissue tolerance has been a major area of research in radiation oncology. A comprehensive set of dose tolerance limits for normal tissue to radiation therapy (RT) became a reference landmark in radiation oncology [4]. In an extensive review of spinal cord irradiation, it was concluded that a dose of $50 \mathrm{~Gy}$ in the spinal cord causes a risk of myelopathy of $0.2 \%$. If the dose increases to $59 \mathrm{~Gy}$ the risk of myelopathy increases to $5 \%$ $[5,6]$. There is consensus regarding the tolerance dose accepted in the spinal cord: with conventional fractionation of $2 \mathrm{~Gy}$ per day including the full cord cross-section, a total dose of 50Gy is associated with a $0.2 \%$ rate of myelopathy; a total dose of $60 \mathrm{~Gy}$ with $6 \%$ rate of myelopathy [7]. As a result, standard RT involving spinal cord treatment delivers a maximum dose of 50Gy with conventional fractionation. Data obtained experimentally indicates that dose reduction per fraction below 2 Gy does not significantly alter the absolute dose-response [5].

\section{Dose and Fractionation}

The biological effects of a physical dose depend on the radiobiological features of the tissue, total dose and fractionation scheme. The outcome of standard clinical radiation treatment is determined by the Rs of radiobiology: Repair, Redistribution, Repopulation, Reoxigenation and Radiosensitivity $[9,10]$.

\section{Repair of Sublethal DNA Damage}

Radiation causes a wide range of lesions in DNA such as SingleStrand Breaks (SSB) and Double-Strand Breaks (DSB). Sub-lethal damage can be repaired if enough time is given between exposures to radiation. SSB can be readily repaired using the undamaged chromatid as a template. The most deleterious lesion induced by ionizing radiation is DSB, a break in both strands of 10 base pairs or less. There are several mechanisms to repair DSBs, which indicate the importance and difficulty of repairing this type of DNA injury. The most important are Non-Homologous End Joining (NHEJ) and Homologous Recombination (HR). Homologous recombination provides greater repair accuracy than NHEJ, the major pathway to repair DSB throughout all the phases of the cell cycle [11]. Redistribution refers to the variation of cellular radiosensitivity according to different phases of the cell cycle: when RT is given to a heterogenous cell population, cells may be in different phases of the cell cycle.
Cells in S phase are more radioresistant and cells in late G2 and $M$ phases are more sensitive. A small dose of radiation will destroy the more sensitive cells, and a resistant cell population that is now synchronized survives. As fractionated radiotherapy treatment continues, the resistant surviving cells will continue throughout the cell cycle and when a new dose is delivered some of these cells have moved from a resistant to a more sensitive stage and radiation will be more effective.

\section{Repopulation}

Sometime after irradiation an increase in cell division is seen in normal and malignant cells. Repopulation occurs at different rates depending on the tissues and represents cell proliferation that aims at compensating the cell population that was killed. This homeostatic response to cell loss occurs in situations other than irradiation and is related to specific cell-cycle time: as a result of radiotherapy cell death occurs after irradiated cells attempt mitosis and thus highly proliferative tissues (and tumors) show damage much faster than slowly proliferative tissues.

\section{Reoxigenation}

The level of oxygenation in a tumor is a major determinant of the effectiveness of radiotherapy. Tumor cell microenvironment presents areas with decreased $\mathrm{pH}$, lack of nutrients and hypoxia. Oxygen concentration (p02) varies between 10- and 80-mm Hg in normal tissues but in tumors these values can be lower than $5 \mathrm{~mm}$ $\mathrm{Hg}$ in some areas. This anomaly is due to the development of abnormal vasculature during tumor angiogenesis. A significant proportion of tumor cells is hypoxic, showing great heterogeneity that is not correlated with standard prognostic factors such as size, stage and histological type. Hypoxia may have a crucial role in treatment outcome and may also influence metastatic capacity of tumor cells resulting from genetic changes such as those involving blood oxygen transport or inducing vascularization. As a result of prolonged exposure to hypoxia, cells can acquire genetic resistance to apoptosis suggesting that hypoxia can favour tumor progression through clonal selection of cells with more aggressive phenotypes [12].

After an initial dose of radiotherapy, the more sensitive oxygenated cells are killed; during reoxygenation, surviving tumor hypoxic cells can increase their oxygen supply thus increasing their sensitivity to radiation. Biological efficacy of ionizing radiation relies on oxygen interacting with cells and making DNA lesions permanent [13]. Dividing total dose in several fractions saves normal tissue due to sublethal damage repair and cell repopulation occurring between treatment fractions. At the same time fractionation allows greater damage to the tumor as a result of reoxygenation of hypoxic cells as well as redistribution of cells into more radiosensitive stages of the cell cycle. Therefore, DNA repair and cell repopulation mechanisms induce normal tissues to become more resistant to a following dose of radiation; the other Rs, namely redistribution and reoxygenation have the opposite effect increasing radiosensitivity of tumor cells. The Rs represent the factors that modify tissue 
response to fractionated radiotherapy - overall radiosensitivity of a specific tumor depends upon a $5^{\text {th }} \mathrm{R}$ : Radiosensitivity that translates the outcome of all the other Rs and represents individual sensitivity to radiation. These five fundamental factors represent the biological basis of radiotherapy $[9,10]$.

\section{Biologically Effective Dose (BED) in Spinal Cord Irradiation}

The Biologically Effective Dose (BED) provides an easy and straightforward way to compare doses from different fractionation schemes, which in turn have different biological effects [14]. The biologically effective dose indicates the radiosensitivity of normal or tumor cells to the effect of radiation. Using BED, it is possible to overcome the difficulty in clinical practice of calculating the total dose when a change in dose per fraction occurs: $B E D=n \times d \times\left[1+d\left(\frac{\alpha}{\beta}\right)\right]$ where $n$ represents the number of fractions and $d$ represents the dose per fraction, with $\left(\frac{\alpha}{\beta}\right)$ representing the sensitivity of the tissue. For acute response tissues the $\left(\frac{\alpha}{\beta}\right)$ ratio is within a range of $7-20 \mathrm{~Gy}$, whereas for late response tissues the $\left(\frac{\alpha}{\beta}\right)$ ratio generally ranges from 0.5-6Gy. The increase in BED values is higher in tissues with low $\left(\frac{\alpha}{\beta}\right)$ ratios, i.e., it is higher in late response tissues than in acute response tissues [14-16].The $\left(\frac{\alpha}{\beta}\right)$ values for cervical and thoracic cord are $2 \mathrm{~Gy}$ or 4Gy, respectively. In this way, a dose of 50Gy given in $2 \mathrm{~Gy}$ daily fractions is equivalent to a BED of $100 \mathrm{~Gy}_{2}$ or $75 \mathrm{~Gy}_{4}\left(\frac{\alpha}{\beta}=4\right)$ [15].

Based on experimental and theoretical considerations, this model is mechanically plausible for designing protocols in the dose range up to $10 \mathrm{~Gy} /$ fraction, and, based on animal data, it is reasonable up to 15 to $18 \mathrm{~Gy}$ per fraction [17]. For a total dose of $34 \mathrm{~Gy}$ to the spinal cord, it is estimated that after 1 -year recovery is $76 \%$. For a total dose of $38 \mathrm{~Gy}$ it is estimated that after 2 years, a recovery of $85 \%$ occurs [2]. Initial dose influences different time intervals from tissue tolerance to reirradiation as well as conditioning the recovery of radiation damage in the first treatment. It is possible to administer a higher dose in the reirradiation if smaller doses were used at the first treatment and if the intervals between treatments were longer $[3,18]$.

\section{Time Interval Between Fractions / Total Treatment Time}

Retreatment in periods shorter than two years may increase the risk of developing complications, since lesions are more likely to develop during this time period [5]. Nevertheless, when the time interval between the first treatment and the retreatment is less than 6 months; the biologically effective dose of each treatment is less of $98 \mathrm{~Gy}_{2}$, no cases of radiation myelopathy where observed when cumulative BED is $\leq 120 \mathrm{~Gy}_{2}$ [15]. Experimental evidence from literature corroborates that the capacity of recovery spinal cord recovery depends on the time interval between the two treatments. Although there is evidence supporting the recovery of the spinal cord, there are still some controversies in the translation of experimental animal data to clinical situations. In schemes with multiple daily fractions it is essential to create an interval between fractions if possible. Due to the catastrophic effect of radiogenic myelopathy repair of sublethal damage in the spinal cord may not be complete after an 8-hour interval [3].

Repair kinetics of the spinal cord is slower, so it is not advantageous to use schemes with time intervals of less than one day. Significant recovery of long-term damage occurs in rat spinal cord [18]. Organ tolerance to reirradiation is influenced by the level of initial damage and time of onset of myelopathy (latency time). Thus, increasing time interval between treatments results in greater recovery and, consequently to lower doses delivered in retreatment $[2,3]$. Time of recovery from damage depends on the tissue or species, as well as on the age of the individual: In animal experiments performed it was observed that 3-week-old mice showed effects faster than adult mice. However, long-term recovery occurred more rapidly in younger rats (3 weeks old) [2,3]. Long-term recovery was observed after 8 weeks and it increased with time interval to retreatment. The initial dose influenced tolerance to retreatment and radiation damage repair at different intervals with long-term recovery after 6 months being approximately $45 \%[3,18,19]$.

\section{Spinal Cord Radiosensitivity}

Radiation injury to the spinal cord is among the most studied experimental models of radiation injury and probably is the most fully documented clinical radiation complication. To the thoracic cord, it is still apparent that its sensitivity to radiation is substantially lower than that of the cervical cord. A significant oxygen effect exists, and it is possible that the thoracic cord is intrinsically less well oxygenated. Extrinsic conditions, such as smoking history or effects of lung cancer may result in the patients with thoracic irradiation having less well oxygenated nervous tissues. Haemoglobin levels are significantly greater in thoracic patients with myelopathy that in those without myelopathy treated to the same dose [20]. The incidence of cervical myelopathy at 45Gy is, approximately, $0.03 \%$ and at $50 \mathrm{~Gy}$ is, approximately $0.2 \%$. Large lengths of spinal cord irradiated, concomitant chemotherapy and other factors may increase this incidence [20].

Spinal cord, besides being one of the most dose-limiting organs in radiotherapy, is also an organ at risk present in several malignant tumors. It is a serial architectural organ, extremely sensitive to radiation in small portions of its extension. There is a possibility that the sensitivity of the spinal cord depends on the organization and structural distribution of its Functional Subunits (FSU), since there are structural differences between the different spinal segments. These differences are mainly patented in grey and white matter $[21,22]$. The effects arising from the volume of irradiated bone marrow may be related to vascular supply, collateral circulation and/or the ability to re-establish damaged vasculature through revascularization. There is also the issue of the release of cytokines and mediators of inflammation. Their release may be affected by the irradiated volume because the larger the volume the greater the release of these potentially harmful substances [5]. 
In summary, recovery from initial damage is well established. The amount of recovery seems to be influenced by different factors, with initial damage expressed as a percentage of cord tolerance being the most important one. Although the general phenomenon of repair occurs in humans caution is necessary when translating experimental animal data to the clinical setting because of the life span, latency and dose response difference 18, [23] as histological pattern of myelopathy in animals differs from those found in humans and repair kinetics is probably different with most studies show a marginal volume effect for cord lengths longer than $1 \mathrm{~cm}$, but a steep increase in tolerance doses for irradiated lengths of less than $1 \mathrm{~cm}$ [24]. In general, a higher retreatment dose can be given following lower initial doses and longer intervals between treatments. From the sparse clinical and primate data, it appears that at least $50 \%$ recovery from 45 Gy would be obtained 2 years after treatment.

\section{Spine Stereotactic Body Radiation Therapy (SBRT)}

Spine SBRT, also known as Spine Stereotactic Radiosurgery (SRS), is an emerging treatment option for patients with spinal bone metastases with or without a soft tissue component and is rapidly being adopted in the clinical setting $[1,20]$. SBRT is a highly effective treatment able to deliver ablative doses to tumors with minimal doses to the surrounding normal tissues. It Is defined as radiotherapy treatment of tumors outside the brain with 1 to 5 dose fractions. It has been made possible in recent years due to advances in image guidance, target visualization and radiation delivery methods that allow large doses delivered to the target while sparing critical organs at risk. Outstanding results already have led to the suggestion that high doses per fraction may have greater efficacy than conventional fractionated radiation therapy $[25,26]$. Initially, this technique was used to successfully treat spinal metastases in a palliative setting. This has led to the widespread extrapolation of SBRT to the treatment of primary spine tumors and for benign tumors of the spinal cord $[27,28]$.

SBRT has specific characteristics that differentiate it from conventional RT: Higher doses per fraction (> 5 Gy) are delivered in one to five fractions, resulting in a high BED value. In several studies, we can verify that reirradiation delivered with SBRT has higher BED values when compared to the first conventional radiotherapy treatment (Table 1); small irradiated cord volume; inhomogeneous dose distribution; short treatment time and greater tumor response with lower normal tissue effects [29,30]: In the limits defined by $[4,6]$ all prescriptions were in 1.8 or $2 \mathrm{~Gy}$ fractions. In contrast, SBRT prescription schemes typically range from 5 Gy per fraction up to $20 \mathrm{~Gy}$ per fraction or more. In this new radiation delivery paradigm, normal organ dose tolerance limits and the dose/volume response of the tumors depend strongly on the number of fractions used and the dose per fraction. Radiation myelopathy is a rare late toxicity effect in the modern era of 3-dimensional conformal conventionally fractionated RT. This devastating late effect is a direct result of SBRT practice, where high-dose radiation is delivered adjacent to the spinal cord to be spared and a better understanding of spinal cord tolerance with high dose per fraction it is therefore essential [31]. Table 1: Variation in BED Value According to Treatment

Schedule.

\begin{tabular}{|c|c|c|c|c|c|}
\hline \multirow[b]{2}{*}{ Author } & \multirow[b]{2}{*}{$\alpha / \beta$ value } & \multicolumn{2}{|c|}{ Initial treatment } & \multicolumn{2}{|c|}{ Reirradiation treatment } \\
\hline & & Dose $f x(G y) / n o f x$ & BED & Dose $f x(G y) / n o f x$ & BED \\
\hline \multirow{2}{*}{ Grousu et al. [39] } & \multirow{2}{*}{2} & $1.25 / 32$ & 65.0 & $1.8 / 16$ & 55.1 \\
\hline & & $1.4 / 20$ & 49.4 & $3.0 / 10$ & 75.0 \\
\hline \multirow{3}{*}{ Wright et al. [43] } & 4 & $3.0 / 10$ & 53.0 & $6 / 5$ & 26.0 \\
\hline & 4 & $3.0 / 15$ & 79.0 & $6 / 5$ & 15.0 \\
\hline & 2 & $3.0 / 11$ & 83.0 & $6 / 5$ & 20.0 \\
\hline \multirow{3}{*}{ Sahgal et al. [31] } & \multirow{3}{*}{2} & $1.8 / 30$ & 102.6 & $8.0 / 3$ & 120.0 \\
\hline & & $0.9 / 28$ & 36.5 & $10.5 / 2$ & 131.3 \\
\hline & & $2.88 / 15$ & 105.4 & $16.0 / 1$ & 144.0 \\
\hline
\end{tabular}

Radiobiology of SBRT: Impact of Repair, Redistribution, Repopulation, Reoxygenation and Radiosensitivity (5rs)

The classical fractionation principles, i.e., the Rs of radiobiology, explain the effects of high doses of ionizing radiation on tumors and adjacent normal tissues. The outcome of standard clinical radiation treatment is determined by the Rs of radiobiology, as previously explained; Tumor hypoxia may actually be a more serious problem with SBRT due to a reduction in reoxygenation between fractions due to the small number of SBRT fractions (1 to 5) in comparison with conventional RT. This problem could be overcome if the following fraction of SBRT could be to deliver after tumor reoxygenation. And although there are no standard intervals between the high doses of SBRT, good clinical results were obtained despite different fractionation intervals [32]. Table 2 attempts so summarize the impact of radiobiological mechanisms in SBRT treatment: 
Table 2: Impact of Radiobiological Mechanisms in SBRT Treatment.

\begin{tabular}{|c|c|}
\hline Biological mechanisms & Description \\
\hline Repair of sublethal damage & $\begin{array}{l}\text { Treatment with SBRT has a longer irradiation time when compared to conventional radiotherapy. With this } \\
\text { treatment, repair of sub-lethal damage may occur during prolonged exposure to radiation. After } 30 \text { minutes, } \\
\text { sublethal damage repair is greater than }>10 \% \text { [33]. }\end{array}$ \\
\hline $\begin{array}{l}\text { Repopulation of cells after } \\
\text { radiation }\end{array}$ & $\begin{array}{c}\text { Repopulation occurs depending on the type of tissue and the dose of radiation administered. In conventional } \\
\text { radiotherapy, tumor cell repopulation occurs within } 2 \text { to } 3 \text { weeks after start of RT. Thus, it is possible that the } \\
\text { repopulation of tumor cells may occur earlier in the treatment of SBRT or SRS than in conventional RT [33]. } \\
\text { Delivering a higher dose should mitigate any clonal expansion and thus offer a significant advantage to rapidly } \\
\text { dividing tumors [46]. As treatment time of SBRT is short, } 2 \text { weeks at most, repopulation of tumor cells should not } \\
\text { be a problem. }\end{array}$ \\
\hline & $\begin{array}{c}\text { Reducing the number of fractions alters the probability of irradiating a cohort of cells as they move into a } \\
\text { radiosensitive phase [46]. }\end{array}$ \\
\hline $\begin{array}{l}\text { Redistribution of cells within the } \\
\text { cell cycle }\end{array}$ & $\begin{array}{l}\text { After irradiation with a single fraction of 15-20Gy, cells are indefinitely arrested in the phases of cell cycle where } \\
\text { they were irradiated and undergo interphase death. After irradiating the cell cycle with a dose of } 20 \mathrm{~Gy} \text { in a single } \\
\text { exposure, cell cycle progression was delayed, and many cells underwent necrosis in the phases of the cycle where } \\
\text { they were irradiated. Cells that were irradiated slowly progressed to the G2 phase and died [33]. }\end{array}$ \\
\hline $\begin{array}{l}\text { Reoxygenation of the surviving } \\
\text { cells }\end{array}$ & $\begin{array}{l}\text { In SBRT, due to the vascular damage caused by the high doses of radiation, the intratumoral environment becomes } \\
\text { hypoxic. Hypoxic cells reoxygenated when irradiated.with a dose not higher than 10Gy. Following administration } \\
\text { of a SBRT or SRS treatment, massive vascular destruction of the tumor occurs, and reoxygenation of hypoxic cells } \\
\text { occurs 2-3 days after irradiation. As oxygen consumption declined dramatically after massive death of tumor cells, } \\
\text { surviving hypoxic cells can reoxygenate. Changes in the oxygenation status of the tumors after irradiation with high } \\
\text { doses are still unclear [33]. SBRT has a theoretical disadvantage because of the short delivery time., although this } \\
\text { might be compensated for through the high doses per fraction of SBRT }\end{array}$ \\
\hline Radiosensitivity & $\begin{array}{l}\text { SBRT attenuates differences in tumor death that are directly attributable to variations in radiation sensitivity of } \\
\text { individual tumor cells. Large doses per fraction and short treatment time used in SBRT provide less opportunity for } \\
\text { the development of resistant stem cells [46]. }\end{array}$ \\
\hline
\end{tabular}

Some radiobiological questions remain unanswered regarding the evaluation of the doses administered in the SBRT and the effect of high doses per fraction. While in conventional radiotherapy the treatment time is approximately 5 minutes, in the SBRT the treatment session takes longer (15-40 minutes). The major question raised when applying these radiobiological principles to SBRT is whether the fractionated dose of radiation administered in daily intervals is equivalent to the few large doses administered without breaks (as repair of sublethal damage occurs within the time interval between the administration of two doses of radiation in conventional fractionation) [33,34]. As SBRT uses doses per fraction much higher than conventional radiotherapy, the radiobiological mechanisms underlying radiation response have been subject to controversy, regarding their application to extreme hypofractionation [34]. Hypofractionation does not follow the basic principles of radiobiology to explain tumor responses obtained by conventional fractionation schemes.

Thus, the relevance of the R's of radiobiology in a scenario of hypofractionation is controversial: As overall treatment time decreases, repopulation will be of lesser importance and the clinical significance of cell redistribution in the cell cycle, in a scenario of hypofractionation, is unclear. In spite of the controversy around the relevance of the 5Rs in SBRT [33,35], it is now clear that these radiobiological concepts are sufficient to explain the impressive results obtained from clinical studies are the result of much larger biologically effective doses delivered [36]. Table 3 presents information regarding $1^{\text {st }}$ treatment and reirradiation data from several studies. Also included are values such as: total dose and the number of fractions delivered, both in the initial treatment and in the retreatment; time elapsed between the end of the first treatment and the retreatment; treatment area (cervical, thoracic, lumbar and sacral); follow-up time and ime until radiation myelopathy appears, should it occur. The Biologically Effective Dose (BED) was calculated when not provided in the original paper as it provides an easy and straightforward way to compare doses from different fractionation schemes. Based on the classification developed by Nieder et al. [15] when the interval between the two treatment courses is not shorter than 6 months and the dose of each course is $\leq 98 \mathrm{~Gy}_{2}$, the cumulative BED where no case of Radiation Myelopathy (RM) has been reported is $120 \mathrm{~Gy}_{2}$; for values between 120 and $135 \mathrm{~Gy}_{2}$, the risk of RM is small. 
Table 3: Summary of Published Reports of Treatments Performed Using Re-Irradiation.

\begin{tabular}{|c|c|c|c|c|c|c|c|c|c|c|c|c|c|}
\hline \multirow{2}{*}{ Author } & \multirow[b]{2}{*}{$\begin{array}{c}\text { Sam- } \\
\text { ple }\end{array}$} & \multicolumn{2}{|c|}{$1^{\text {st }}$ treatment } & \multirow[b]{2}{*}{$\begin{array}{c}\text { Interval } \\
\text { (months) }\end{array}$} & \multicolumn{2}{|c|}{ Reirradiation } & \multirow[b]{2}{*}{$\begin{array}{c}\text { Nivel } \\
\text { trea- } \\
\text { ted }\end{array}$} & \multirow[b]{2}{*}{$\begin{array}{c}\text { Value } \\
\text { of } \\
\alpha / \beta \\
\text { (Gy) }\end{array}$} & \multirow[b]{2}{*}{$\begin{array}{c}\text { Initial } \\
\text { BED }\end{array}$} & \multirow[b]{2}{*}{$\begin{array}{l}\text { Irra- } \\
\text { diation } \\
\text { BED }\end{array}$} & \multirow[b]{2}{*}{$\begin{array}{l}\text { Total } \\
\text { BED }\end{array}$} & \multirow[b]{2}{*}{$\begin{array}{c}\text { Follow- } \\
\text {-up } \\
\text { (mon- } \\
\text { ths) }\end{array}$} & \multirow[b]{2}{*}{$\begin{array}{c}\text { Time to } \\
\text { myelo- } \\
\text { pathy } \\
\text { (mon- } \\
\text { ths) }\end{array}$} \\
\hline & & $\begin{array}{l}\text { Total dose } \\
\text { (Gy) }\end{array}$ & Dose $f x(G y) / n o f x$ & & $\begin{array}{l}\text { Total dose } \\
\text { (Gy) }\end{array}$ & $\begin{array}{c}\text { Dose } f x(G y) / \\
\text { no } f x\end{array}$ & & & & & & & \\
\hline \multirow{11}{*}{$\begin{array}{l}\text { Wong et } \\
\text { al. [37] }\end{array}$} & \multirow{11}{*}{11} & $2.0+45.9$ & $2.0 / 1+3.06 / 15$ & 12 & 23.6 & $2.36 / 10$ & $\mathrm{~T}$ & \multirow{11}{*}{2} & 120.13 & 51.45 & 171.58 & \multirow{11}{*}{$\geq 60$} & 4 \\
\hline & & $23.5+18.2$ & $2.35 / 10+3.64 / 5$ & 19 & 13.6 & $2.72 / 5$ & $\mathrm{~T}$ & & 102.44 & 32.096 & 134.54 & & 16 \\
\hline & & 20.6 & $3.43 / 6$ & 4 & 36.4 & $3.64 / 10$ & $\mathrm{~T}$ & & 55.93 & 102.65 & 158.58 & & 6 \\
\hline & & 20.1 & $1.26 / 16$ & 48 & $\begin{aligned} & 14.3+3.2 \\
+ & 22.6+2.57\end{aligned}$ & $\begin{array}{l}2.38 / 6+1.6 / 2+ \\
3.76 / 6+2.57 / 1\end{array}$ & $\mathrm{~T}$ & & 33.25 & 108.04 & 141.29 & & 11 \\
\hline & & 16.0 & $3.2 / 5$ & 57 & 22.0 & $7.33 / 3$ & $\mathrm{~T}$ & & 41.60 & 102.63 & 144.23 & & 7 \\
\hline & & $24.0+24.0$ & $3.0 / 8+1.5 / 16$ & 45 & 18.1 & $1.81 / 10$ & $\mathrm{~T}$ & & 102.00 & 34.48 & 136.48 & & 13 \\
\hline & & $20.4+20.3$ & $4.08 / 5+4.06 / 5$ & 10 & 8.2 & $8.2 / 1$ & $\mathrm{~T}$ & & 123.53 & 41.82 & 165.35 & & 4 \\
\hline & & 24.4 & $4.88 / 5$ & 2 & 17.0 & $3.4 / 5$ & $\mathrm{~T}$ & & 83.94 & 45.9 & 129.84 & & 14 \\
\hline & & 31.2 & $1.56 / 20$ & 71 & 30.3 & $5.05 / 6$ & $\mathrm{C}$ & & 55.54 & 106.81 & 162.35 & & 25 \\
\hline & & 33.9 & $3.39 / 10$ & 2 & 25.6 & $2.56 / 10$ & $\mathrm{~T}$ & & 91.36 & 58.9 & 150.4 & & 13 \\
\hline & & 50.0 & $2.5 / 20$ & 27 & 10.4 & $1.04 / 10$ & $\mathrm{~T}$ & & 112.50 & 15.81 & 128.31 & & 11 \\
\hline \multirow{3}{*}{$\begin{array}{l}\text { Schiff et } \\
\text { al. [38] }\end{array}$} & \multirow{3}{*}{54} & 30.0 & $3.0 / 10$ & \multirow{3}{*}{$\begin{array}{l}\text { Median } \\
\text { 9.1 (range: } \\
\text { 1-51.3) }\end{array}$} & 30.6 & $1.8 / 17$ & $\mathrm{~T}$ & \multirow{3}{*}{3} & 60.0 & 48.96 & 108.96 & \multirow{3}{*}{4.2} & \multirow{3}{*}{ No cases } \\
\hline & & 30.0 & $3.3 / 9$ & & 39.6 & $1.8 / 22$ & $\mathrm{~L}$ & & 63.0 & 63.36 & 126.36 & & \\
\hline & & 30.0 & $3.0 / 10$ & & 22.0 & $2.0 / 11$ & $\mathrm{C} / \mathrm{T}$ & & 60.0 & 36.7 & 96.7 & & \\
\hline \multirow{8}{*}{$\begin{array}{l}\text { Sminia } \\
\text { et al. } \\
\text { [45] }\end{array}$} & \multirow{8}{*}{8} & 16.0 & $8.0 / 2$ & 52 & 20.0 & $4.0 / 5$ & $\mathrm{~T}$ & & 80.0 & 60.0 & 140.0 & & \\
\hline & & 39.0 & $3.0 / 13$ & 12 & 21.0 & $3.0 / 7$ & $\mathrm{~T}$ & & 97.5 & 52.2 & 149.7 & & \\
\hline & & 8.0 & $8.0 / 1$ & 4 & 18.0 & $3.0 / 6$ & $\mathrm{C}$ & & 40.0 & 45.0 & 125.0 & & \\
\hline & & 49.6 & $1.6 / 31$ & 61 & 50.0 & $2.0 / 25$ & $\mathrm{~L}$ & & 69.4 & 75.0 & 144.4 & & \\
\hline & & 37.4 & $2.2 / 17$ & 61 & 21.0 & $3.0 / 7$ & $\mathrm{~T}$ & 2 & 78.5 & 52.2 & 130.7 & $1-54$ & No cases \\
\hline & & 24.0 & $3.0 / 8$ & 30 & 21.0 & $3.0 / 7$ & $\mathrm{~T}$ & & 60.0 & 52.2 & 164.4 & & \\
\hline & & 25.0 & $1.7 / 15$ & 20 & 16.0 & $4.0 / 4$ & $\mathrm{~T}$ & & 46.0 & 48.0 & 142.0 & & \\
\hline & & 35.25 & $1.5 / 23.5$ & $\begin{array}{l}150 \\
73\end{array}$ & 30.0 & $3.0 / 10$ & $\mathrm{~L}$ & & 48.5 & 52.5 & 125.0 & & \\
\hline & & 40.0 & $1.25 / 32$ & & 29.0 & $1.8 / 16$ & $\mathrm{~T}$ & & 65.0 & 55.1 & 120.1 & & \\
\hline & & 30.0 & $3.0 / 10$ & & 30.0 & $2.0 / 15$ & $\mathrm{~L}$ & & 75.0 & 60.0 & 135.0 & & \\
\hline & & 40.0 & $2.5 / 16$ & & 30.6 & $1.8 / 17$ & $\mathrm{~T} / \mathrm{L}$ & & 90.0 & 58.1 & 148.1 & & \\
\hline Grosu et & 8 & 40.0 & $2.0 / 20$ & Median 30 & 30.6 & $1.8 / 17$ & $\mathrm{~T}$ & 2 & 80.0 & 58.1 & 138.1 & $\begin{array}{c}\text { Median } \\
16\end{array}$ & Jocos \\
\hline al. [39] & 8 & 50.0 & $2.0 / 25$ & (range: 6-63) & 18.0 & $3.0 / 6$ & $\mathrm{~T}$ & 2 & 100.0 & 45.0 & 145.0 & $\begin{array}{l}\text { (range: } \\
5-44 \text { ) }\end{array}$ & No cases \\
\hline & & 30.0 & $3.0 / 10$ & & 30.0 & $2.0 / 15$ & $\mathrm{~T}$ & & 75.0 & 60.0 & 135.0 & & \\
\hline & & 29.0 & $1.4 / 20$ & & 30.0 & $3.0 / 10$ & $\mathrm{~T}$ & & 49.4 & 75.0 & 124.4 & & \\
\hline & & 36.0 & $3.0 / 12$ & & 30.0 & $2.0 / 15$ & $\mathrm{~L}$ & & 90.0 & 60.0 & 150.0 & & \\
\hline & & 40.0 & $2.67 / 15$ & & 20.0 & $4.0 / 5$ & $\mathrm{SC}$ & 2 & 93.0 & 11.0 & 104.0 & & \\
\hline Wright & & 30.0 & $3.0 / 10$ & & 20.0 & $4.0 / 5$ & $\mathrm{CE}$ & 4 & 53.0 & 4.0 & 57.0 & 8 & \\
\hline et al. & 37 & 30.0 & $3.0 / 10$ & $\begin{array}{c}\text { Median } 19 \\
(2-125)\end{array}$ & 20.0 & $4.0 / 5$ & SC & 2 & 75.0 & 17.0 & 92.0 & range & No cases \\
\hline & & 50.4 & $1.8 / 28$ & & 20.0 & $4.0 / 5$ & $\mathrm{CE}$ & 4 & 73.0 & 9.0 & 82.0 & $1-51)$ & \\
\hline & & 37.7 & $2.51 / 15$ & & 20.0 & $4.0 / 5$ & $\mathrm{SC}$ & 2 & 85.0 & 20.0 & 105.0 & & \\
\hline
\end{tabular}

A. Analyzing data from Table 3 it is possible to notice that in the data presented by Wong et al., [37]: a patient received $20.6 \mathrm{~Gy}$ in the $1^{\text {st }}$ treatment in 6 fractions and was retreated after 4 months.

B. $\quad B E D$ for $2^{\text {nd }}$ treatment was $102.65 \mathrm{~Gy}_{2}$; cumulative BED was $158.58 \mathrm{~Gy}_{2}$. His risk score was 4 , wich presented an intermediate risk of developing myelopathy, which occurred after 6 months;
C. Results presented by Schiff et al. [38], Grosu et al. [39], Nieder et al. [15] and Maranzano et al. [40]: showed that the cases reported had a time interval between treatments of more than 6 months, BED is $\leq 98 \mathrm{~Gy}_{2}$ for each treatment, cumulative $\mathrm{BED}=120 \mathrm{~Gy}_{2}$ and no cases of myelopathy were reported;

Most studies related to reirradiation are based on data from retrospective studies or small prospective studies. In addition 
to this, re-irradiated populations are more heterogeneous than patients with local or regional recurrence or second tumors [41] The major paradigm associated with spinal cord reirradiation is related to the lack of evidence regarding repair of long-term damage in this organ. There is a greater uncertainty related to tolerance rates during reirradiation, since most of the existing data are derived from results obtained with animals, revealing long-term damage recovery [42-46]. As SBRT is increasingly being employed in the treatment of spinal lesions, and although reports of toxicity are rare, the follow-up time is short and patient numbers are still small. The effect of concurrent chemotherapy is essentially unknown and needs to be investigated.

The optimal dose prescription for SBRT remains controversial. On the one hand, larger doses per fraction result in better local control rates than obtained with conventional RT. This may be the result of larger biologically effective doses delivered with SBRT. Alternatively, higher rates of local control following low fraction number in retrospective series may simply reflect better outcomes in patients with less aggressive disesase [42].

\section{References}

1. Hashmi A, Tanaka H, Wong S (2016) Spinal cord dose limits for stereotactic body radiotherapy. In: Sahgal A, Lo Simon, Ma Lijun, Sheehan, Jason (Eds.), Image-Guided Hypofractionated Stereotatic Radiosurgery, Boca Raton, CRC Press, Florida, pp. 325-330.

2. Kirkpatrick J van der Kogel AJ, Schultheiss TE (2010) Radiation dosevolume effects in the spinal cord. International Journal of Radiation Oncology Biology Physics 76(3): S42-S49.

3. Supe SS, Ganesh KM, Naveen T, Jacob S, Sankar BN (2006) Spinal cord response to altered fractionation and re-irradiation: Radiobiological considerations and role of bioeffect models. Journal of Cancer Research and Therapeutics 2(3): 105-118.

4. Emami B, Lyman J, Brown A, Coia L, Goitein M, et al. (1991) Tolerance of normal tissue to therapeutic radiation. International Journal of Radiation Oncology Biology Physics 21(1): 109-122.

5. Gocheva L (2000) Radiation tolerance of the spinal cord: doctrine, dogmas, data. Archive of Oncology 8(3): 131-134.

6. Emami B, Lyman J, Brown A, Coia L, Goitein M, et al. (2013) Tolerance of Normal Tissue to Therapeutic Radiation. Int J Radiat Oncol Biol Phys 21(1):109-122.

7. Marks LB, Yorke ED, Jackson A, Haken RK, Constine LS, et al. (2010) Use of normal tissue complication probability models in the clinic. International Journal of Radiation Oncology Biology Physics 7(3): S10-S19.

8. Wilson G (2007) Cell kinetics. Clin Oncol 19(6): 370-384

9. Brown J, Carlson DJ, Brenner D (2014) The Tumor Radiobiology of SRS and SBRT: Are More Than the 5 Rs Involved. International Journal of Radiation Oncology Biology Physics 88(2): 254-262.

10. Hall E, Giaccia A (2012) Radiobiology for the Radiologist, ( $7^{\text {th }}$ Edn.), Lippincott, pp. 432-447.

11. DC van Gent, JH Hoeijmakers, R Kanaar (2001) Chromosomal stability and the DNA double-stranded break connection. Nat Rev Genet 2(3): 196-206.

12. Wouters G, Koritzinsky M (2009) The tumor microenvironment and cellular hypoxia responses. In: Joiner M, van der Kogel, An Arnold Pub (Eds.), Basic Clinical Radiobiology, pp. 121-137.
13. Wouters B, Begg A (2009) Irradiation-induced damage and the DNA damage response. In: Joiner M, van der Kogel, A. Arnold Pub (Eds.), Basic Clinical Radiobiology, p. 11-26.

14. Dale RG (1985) The application of the linear-quadratic dose effect equation to fractionated and protracted radiotherapy. $\mathrm{Br} \mathrm{J}$ Radiol 58(690): 515-528.

15. Nieder C, Grosu AL, Andratschke NH, Molls M (2006) Update of human spinal cord reirradiation tolerance based on additional data from 38 patients. International Journal of Radiation Oncology Biology Physics 66(5): 1446-1449.

16. Joiner M, Kogel A (2009) Basic Clinical Radiobiology. Great Britain: Hodder Arnold.

17. Brenner DJ (2008) The Linear-Quadratic Model Is an Appropriate Methodology for Determining Isoeffective Doses at Large Doses Per Fraction. Seminars in Radiation Oncology 18(4): 234-239.

18. Supe SS, Ganesh KM, Velmurugan J, Rana BS, Sankar BN (2002) Radiobiological considerations of re-irradiation tolerance of the spinal cord. Reports of Practical Oncology and Radiotherapy 7(2): 81-85.

19. Nieder C, Milas L, Ang KK (2000) Tissue Tolerance to Reirradiation. Seminars in Radiation Oncology 10(3): 200-209.

20. Schultheiss TE (2008) The Radiation Dose-Response of the Human Spinal Cord. International Journal of Radiation Oncology Biology Physics 71(5): 1455-1459.

21. Bijl HP, van Luijk P, Coppes RP, Schippers JM, Konings AW, et al. (2003) Unexpected changes of rat cervical spinal cord tolerance caused by inhomogeneous dose distributions. International Journal of Radiation Oncology Biology Physics 57(1): 274-281.

22. Adamus Górka M, Brahme A, Mavroidis P, Lind BK (2008) Variation in radiation sensitivity and repair kinetics in different parts of the spinal cord. Acta Oncologica 47(5): 928-936.

23. Schultheiss TE, Stephens LC, Jiang GL (1990) Radiation myelopathy in primates treated with conventional fractionation. International Journal of Radiation Oncology Biology Physics 19(4): 935-940.

24. Kogel AJ (1993) Dose-volume effects in the spinal cord. Radiotherapy and Oncology Journal of the European Society for Therapeutic Radiology and Oncology 29: 105-109.

25. Foote M, Letourneau D, Hyde D, Massicotte E, Rampersaud R, et al. (2011) Technique for stereotactic body radiotherapy for spinal metastases. Journal of Clinical Neuroscience 18(2): 276-279.

26. Brown JM, Carlson DJ, Brenner DJ (2014) The tumor radiobiology of SRS and SBRT: Are more than the 5 Rs involved. International Journal of Radiation Oncology Biology Physics 88(2): 254-262.

27. Tseng CL, Eppinga W, Charest-Morin R, Soliman H, Myrehaug S, et al. (2017) Spine Stereotactic Body Radiotherapy: Indications, Outcomes, and Points of Caution. Global Spine Journal 7(2): 179-197.

28. Al Omair A, Masucci L, Masson-cote L, Campbell M, Atenafu EG, et al. (2013) Surgical resection of epidural disease improves stereotactic body radiotherapy. Neuro-Oncology 15(10): 1413-1419.

29. Timmerman RD, Herman J, Cho LC (2014) Emergence of stereotactic body radiation therapy and its impact on current and future clinical practice. Journal of Clinical Oncology 32(26): 2847-2854.

30. Garau MM (2017) Radiobiology of stereotactic body radiation therapy (SBRT). Reports of Practical Oncology and Radiotherapy 22(2): 86-95.

31. Sahgal A, Ma L, Weinberg V, Gibbs IC, Chao S, et al. (2012a) Reirradiation human spinal cord tolerance for stereotactic body radiotherapy. International Journal of Radiation Oncology Biology Physics 82(1): 107116.

32. Hong BJ, Kim J, Jeong H, Bok S, Kim YE, et al. (2016) Tumor hypoxia and reoxygenation: the yin and yang for radiotherapy. Radiat Oncol J 34(4): 239-249. 
33. Kim MS, Kim W, Park IH, Kim HJ, Lee E, et al. (2015) Radiobiological mechanisms of stereotactic body radiation therapy and stereotactic radiation surgery. Radiation Oncology Journal 33(4): 265-275.

34. Nagata Y (2015) Stereotactic Body Radiation Therapy: Principles and Practices. Springer Japan.

35. Fuks Z, Kolesnick R (2005) Engaging the vascular component of the tumor response. Cancer Cell 8: 89-91.

36. Brown JM (2018) The Biology of SBRT: LQ or Something New. International Journal of Radiation Oncology Biology Physics 101(2): 964.

37. Wong CS, Van Dyk J, Milosevic M, Laperriere NJ (1994) Radiation Mielopathy Following Single Courses of Radiotherapy and Retreatment. International Journal of Radiation Oncology Biology Physics 30(3): 575581.

38. Schiff D, Shaw EG, Cascino TL (1995) Outcome after Spinal Reirradiation for Malignant Epidural Spinal Cord Compression. Annals of Neurology 37(5): 583-589.

39. Grosu AL, Andratschke N, Nieder C, Molls M (2002) Retreatment of the Spinal Cord with Palliative Radiotherapy. International Journal of Radiation Oncology Biology Physics 52(5): 1288-1292.

40. Maranzano E, Trippa F, Casale M, Anselmo P, Rossi R (2011) Reirradiation of metastatic spinal cord compression: Definitive results of two randomizedd trials. Radiotherapy and Oncology 98(2): 234-237.

\section{ISSN: 2574-1241}

DOI: 10.26717/BJSTR.2019.23.003977

Isabel Bravo. Biomed J Sci \& Tech Res

(C) This work is licensed under Creative

Submission Link: https://biomedres.us/submit-manuscript.php
41. Nieder C, Langendijk JA (2011) Re-Irradiation: New Frontiers. In: C Nieder, JA Langendijk (Eds.), Berlin: Springer, Germany.

42. Redmond, Lo SS, Soltys SG, Yamada Y, Barani IJ, et al. (2017) Consensus Guidelines for Postoperative Stereotactic Body Radiation Therapy for Spinal Metastases: Results of an International Survey. Journal of Neurosurgery Spine 26(3): 299-306.

43. Wright JL, Lovelock DM, Bilsky MH, Toner S, Zatcky J, et al. (2006) Clinical Outcomes After Reirradiation of Paraspinal Tumors. American Journal of Clinical Oncology 29(5): 495-502.

44. Sahgal A, Weinberg V, Ma L, Chang E, Chao S, et al. (2012b) Probabilities of radiation myelopathy specific to stereotactic body radiation therapy to guide safe practice. International Journal of Radiation Oncology Biology Physics 85(2): 341-347.

45. Sminia P, Oldenburger F, Slotman BJ, Scchneider CJ, Hulshof MC (2002) Re-Irradiation of the Human Spinal Cord. Strahlentherapie und Onkologie 178(8): 453-456

46. Vaughan A, Rao SSD (2016) Radiobiology of Stereotactic Radiosurgery and Stereotactic Body Radiotherapy. In: Sethi RA, et al. (Eds.), Handbook of Evidence-Based Stereotactic Radiosurgery and Stereotatic Body Radiotherapy, Springer, Switzerland, p. 11-19.

$\begin{array}{ll}\text { BIOMEDICAL } & \text { Assets of Publishing with us } \\ \text { RESEARCHES } & \text { - Global archiving of articles } \\ \text { - Immediate, unrestricted online access } & \text { - Rigorous Peer Review Process } \\ & \text { - Authors Retain Copyrights } \\ \end{array}$

